\title{
UNCONVENTIONAL TAX MECHANISMS IN A SECULAR STATE: PROSPECTS OF ADOPTATION IN RUSSIA
}

\author{
Nadezhda A. Lvova \\ St. Petersburg State University, St. Petersburg, Russia \\ Natalia V. Pokrovskaia \\ St. Petersburg State University, Russia \\ Viktor V. Ivanov \\ St. Petersburg State University, Russia
}

\begin{abstract}
This article focuses on the prospects of adapting unconventional tax mechanisms to tax management of a secular multicultural nation. The purpose of the study was to evaluate tolerance factors to socially oriented taxation as viewed by those not well aware about religious taxation policy. Research methods implied using the interview approach. The respondents were would be economist studying at St Petersburg State University. The first stage checked respondents' level of awareness of the research subject. During the second stage, an ordered logit regression method was used to generate a model of tolerance to socially oriented taxation. It was proven that the level of commitment here depends on how respondents perceive social responsibility including its implementation mechanisms. The survey results showed that respondents rather unaware of unconventional tax mechanisms demonstrated high level of readiness to assume additional social obligations. It appears that the survey results are of scholarly importance in terms of developing the understanding of modern tax mechanisms and religious and socially oriented taxation. Besides, they may find their practical application in tax management in secular multicultural nations.
\end{abstract}

Keywords: tax mechanism, unconventional tax mechanism, religious taxes, Islamic taxes

JEL code: $\mathrm{H} 24$

\section{Introduction}

The idea of social equity is as old as the hills or, to be more specific, as the state. The latter in its turn is unthinkable without taxes. Thus, interrelation among the ideas of social equity, taxes and the state is unquestionable. The way that forms and methods of tax collection develop in time reflects the changes in society's understanding of governmental functions. Social aspects play nowadays the key part in creating taxation systems. Quickly developing concepts of general welfare and sustainable economic growth, growing social insurance crisis and other challenges of the past decades make it relevant to search for efficient tax mechanisms and alternative approaches towards taxation, what is especially important and promising for secular multicultural states.

It is generally thought that distinct socially oriented taxes appeared no earlier than in the 20th century. However, taking into account religious taxes and charges, this point of view is no longer as obvious. Namely, tithe was paid from the earliest times and steered into social purposes at least partially. Today religious taxation is widely used in Muslim countries. The list and content of Islamic taxes is a matter of active discussion in scientific circles (for more detail see Bekkin, 2007). One of the most important questions is whether zakat is a tax by its nature (a detailed review of this scientific discussion is given here: Shaikh, 2006). It should be noted that Islamic taxation is considered mainly from the legal (Saleem, 1992; Al-Qardawi, 200; Powell, 2009) and organizational (Awad, 2000; Yusuf and Derus, 2013) points of view. The social role of Islamic taxation was studied in the following works: Abdullah et al., 2015; 
Mohd et al, 2015. In this relation, it should be emphasized that a socially oriented tax zakat is one of the Five Pillars of Islam (Surah 9, At-Tawbah (The Repentance)).

Accordingly, we suggest that a review of the religious tax collection practice and theory behind it, we decided to take a fresh look into the problems of efficient tax management, what has determined the purpose of our research. Namely we sought to determine the factors that influence the level of tolerance towards socially oriented taxation as viewed by respondents not well aware about alternative taxation practices, corresponding implementation mechanisms and Islamic finance system including taxation.

\section{Theory}

Socially oriented taxation is an important phenomenon of Islamic world of finances. The beginning of modern finance system is typically dated from the 1960s-1970s. First Islamic financial intermediaries started their work in Egypt and Malaysia. In 1973, a most important international institution was founded, namely the Islamic Development Bank. In the late 1970s - early 1980s noninterest economic institutions started their international expansion. The first non-Muslim country to open an Islamic investment company in 1978 was Luxembourg. The first Islamic retail bank in Europe started operation in 2004 in the United Kingdom. Islamic financial industry is deemed to be a significant phenomenon of financial economics in the 21 st century. Today all its key elements can be observed: financial markets, institutions, instruments and supporting infrastructure (Gordeeva and Lvova, 2009). Islamic financial system shows high financial growth rates (Islamic Financial Services Industry Stability Report 2015), but its structure is disproportionate and fragmentary: over $90 \%$ of Islamic financial assets accrue to a banking sector (Islamic Finance, 2013), the bulk of resources is accumulated in the Middle Eastern countries and Southeast Asia. The prospects of Islamic financial system are closely related to Muslim population. In Russia it is considered to be about $10 \%$ of total population (Religious Diversity Index Scores by Country). The most part of those live in the Volga region and the North Caucasus. Islamic financial mechanisms are considered promising in terms of using them in these regions.

Islamic finances are subject to special requirements, i.e. Sharia Islamic Law. Pertaining to tax mechanisms implementation, Islamic financial system features are associated with the priority of ethics within this particular economic system. Islam does not rule out social inequality but insists on providing equal opportunities and condemns unjust enrichment. In this respect, the key financial principals are a ban on interest rate, profiteering, excessive risk and funding illegal activity; as well as a requirement to pay a special tax, namely zakat.

Zakat is the central point of Islamic taxation system, it comprises a group of mandatory payments that impose different objects and classes of payers with various tax-exempt minimum and graduated rates. Such payments comply with uniform principles of levying taxes and their redistribution (Lvova and Pokrovskaia, 2015):

1) They have binding effect on Muslims based on their religious duty. Thus, fiscal instruments of enforcing tax payment are replaced with motivation that mainly calls upon personal responsibility of a tax payer.

2) They have a strictly regulated time frame and size of payments. Zakat size and payment terms comply with Sharia law requirements, which can be found in Quran, Sunnah and their interpretations.

3) They have regulated expenditure purposes (provided by Quran, see Surah 9, At-Tawbah). Tax revenue can be used for the benefit of the following categories: the poor and the needy, those employed to collect zakat, those bringing hearts together for Islam, for freeing slaves, for those in debt, for those committed to the cause of Allah and travelers. 
4) They can be administrated outside governmental institutions that traditionally maintain law and guarantee the indispensability of levying taxes in a secular society.

If we abstract away from the religious component, it will be possible to separate a number of essential features of zakat. First, zakat is a purification tax and not a donation, what is reflected in motives and mechanisms of its collection. Second, the purposes of taxation are subject to the principles of social equality. Thus, from the financial point of view, the nature of zakat is about being a special tax targeted at the support of different population groups (mainly disadvantaged ones). Next, zakat payers are exclusively Muslims.

Thus, regional structure of the Islamic taxation system is not always the same as the administrative and territorial division of existing countries. Besides, Muslims are exposed to double taxation by paying not only zakat, but also conventional taxes to their tax jurisdiction. Zakat is a part of national taxation systems in Yemen, Libya, Malaysia, Pakistan, Saudi Arabia and Sudan. Nine more countries (Bangladesh, Bahrain, Egypt, Indonesia, Jordan, Iran, Kuwait, Lebanon and the United Arab Emirates) support zakat to some extent through tax reliefs for its payers (including mitigation of double taxation) and by taking part in controlling its expenditure and/or redistribution. Other Muslim countries do not take part in administering zakat. This is especially true for countries where Islam is not a dominating religion. It is not difficult to guess that zakat is not a part of taxation system in Russia. However, it is voluntarily paid by Muslims to non-government funds.

\section{Data and methods}

It should be noted that the interview approach is widely used in the research of Islamic finance. At the same time such studies, as a rule, focus on financial industry (Kallimullina, 2010; Masvood and Lokeswara Choudary, 2015). A work performed by R. Mohdali and J. Pope (2014) is an interesting exception and proves the hypothesis that religious commitment positively affects the commitment to paying taxes. For the research purpose, would-be economists, bachelor degree program students of economics at St Petersburg State University of the 2, 3 and 4 years were interviewed. 127 people filled out questionnaires (the interview was done in 2015). Participation in the survey was voluntary with random selection of respondents. The descriptive statistics of the survey is provided below (Table 1).

Table 1. Key descriptive characteristics of the survey

\begin{tabular}{|l|c|c|c|c|}
\hline & $\begin{array}{c}\text { Second-year } \\
\text { Students }\end{array}$ & $\begin{array}{c}\text { Third-year } \\
\text { Students }\end{array}$ & $\begin{array}{c}\text { Fourth-year } \\
\text { Students }\end{array}$ & Total Number \\
\hline Female & 18 & 44 & 46 & 108 \\
\hline Male & 4 & 7 & 8 & 18 \\
\hline Total Number & 22 & 51 & 54 & 127 \\
\hline
\end{tabular}

The questionnaire included 20 statements that comprised two concept blocks: the first one referred to the perception of social equality and the second one referred to the awareness level of respondents in terms of the survey subject (Table 2).

Every respondent was invited to rate the statements with the negative expressions like 'strongly disagree' and 'disagree' or the positive ones, such as 'agree' and 'strongly agree'. Besides, there was an option to mark their answer as 'neither agree nor disagree'. 
Table 2. Questionnaire contents

\begin{tabular}{|c|c|}
\hline $\begin{array}{c}\text { Questions } \\
\text { on social equality }\end{array}$ & $\begin{array}{c}\text { Questions } \\
\text { checking awareness of the survey subject }\end{array}$ \\
\hline $\begin{array}{l}\text { 1. Financial relations should comply with strict } \\
\text { ethical principles }\end{array}$ & $\begin{array}{l}\text { 11. I am aware of particular nature of religious taxes } \\
\text { and charges }\end{array}$ \\
\hline $\begin{array}{l}\text { 2. Financial system should benefit socially fair } \\
\text { distribution of profit in a society }\end{array}$ & $\begin{array}{l}\text { 12. Religious taxation is expedient regardless of per } \\
\text { capita income }\end{array}$ \\
\hline $\begin{array}{l}\text { 3. Financial support of socially disadvantaged groups } \\
\text { of people should be provided by the government }\end{array}$ & $\begin{array}{l}\text { 13. Religious taxation is economically justified in } \\
\text { countries with high percentage of believers }\end{array}$ \\
\hline $\begin{array}{l}\text { 4. Financial support of socially disadvantaged groups } \\
\text { of people is a mandatory component for businesses in } \\
\text { terms of social responsibility }\end{array}$ & $\begin{array}{l}\text { 14. Religious taxes and charges are as a rule } \\
\text { collected by specialized religious organizations }\end{array}$ \\
\hline $\begin{array}{l}\text { 5. Society as a whole is responsible for the financial } \\
\text { support of the socially disadvantaged people }\end{array}$ & $\begin{array}{l}\text { 15. Religious taxes and charges are not a part of } \\
\text { Russian taxation system }\end{array}$ \\
\hline $\begin{array}{l}\text { 6. A special tax should be introduced in order to } \\
\text { provide support for the socially disadvantaged }\end{array}$ & $\begin{array}{l}\text { 16. I am aware of particular nature of Islamic } \\
\text { finances }\end{array}$ \\
\hline $\begin{array}{l}\text { 7. Non-government funds with freely available and } \\
\text { transparent accounting statements should collect and } \\
\text { distribute money for the support of the disadvantaged }\end{array}$ & $\begin{array}{l}\text { 17. The key principle of Islamic finances is the ban } \\
\text { for interest rate }\end{array}$ \\
\hline $\begin{array}{l}\text { 8. I am ready to refuse from a part of income in order } \\
\text { to support the disadvantaged }\end{array}$ & $\begin{array}{l}\text { 18. Islamic finances exist in both Muslim and non- } \\
\text { Muslim countries }\end{array}$ \\
\hline $\begin{array}{l}\text { 9. I am ready to make donations to specialized non- } \\
\text { government funds in order to support the } \\
\text { disadvantaged }\end{array}$ & 19. I am aware of particular nature of Islamic taxes \\
\hline $\begin{array}{l}\text { 10. Expenditures for the support of the disadvantaged } \\
\text { should influence the income tax for private persons }\end{array}$ & 20. Islamic taxes operate in Russia \\
\hline
\end{tabular}

The first stage of the research was to test the hypothesis that respondents were not well aware of the research subject.

At the second stage, a model was built to determine the level of respondents' tolerance towards socially oriented taxation with a mock tax as an example featuring zakat attributes.

Hypotheses were formulated the following way:

$H_{0}$ : tolerance towards the introduction of a corresponding tax does not depend on personal (individual perception of social responsibility) and impersonal (gender, study year) factors.

$H_{l}$ : tolerance towards the introduction of a corresponding tax depends on the researched factors.

\section{Findings}

The distribution of the obtained answers is presented in Table 3.

Our research was initially based on an assumption that respondents would not be well aware of the research subject. This hypothesis received a sufficiently complete confirmation.

Only $10 \%$ of students answered they were aware of particular nature of Islamic finances and that those implied mandatory socially oriented taxation for citizens (mainly Muslims) and entities (including financial intermediaries). At the same time $32 \%$ of respondents chose the right answer that the key principle of Islamic finances is the ban for interest rate. However, only $14 \%$ believed that Islamic financial system operated in both Muslim and non-Muslim countries.

Thus, the subjective assessment of low awareness level was confirmed only partially and, therefore, could be considered as an overly conservative estimate. We believe this can be explained through respondents' dissatisfaction with their knowledge regarding the subject and 
their potential interest in studying it later on. As for the awareness of religious taxes and charges, $80 \%$ of students reported their ignorance on the subject.

Table 3. Distribution of respondents' answers

\begin{tabular}{|c|c|c|c|c|c|}
\hline $\begin{array}{c}\text { Number of the } \\
\text { question }\end{array}$ & $\begin{array}{l}\text { 'neither agree } \\
\text { nor disagree' }\end{array}$ & $\begin{array}{l}\text { 'strongly } \\
\text { disagree' }\end{array}$ & 'disagree' & 'agree' & $\begin{array}{c}\text { 'strongly } \\
\text { agree' }\end{array}$ \\
\hline 1 & $1 \%$ & $3 \%$ & $20 \%$ & $59 \%$ & $17 \%$ \\
\hline 2 & $0 \%$ & $2 \%$ & $13 \%$ & $47 \%$ & $38 \%$ \\
\hline 3 & $0 \%$ & $2 \%$ & $2 \%$ & $39 \%$ & $57 \%$ \\
\hline 4 & $0 \%$ & $4 \%$ & $48 \%$ & $39 \%$ & $9 \%$ \\
\hline 5 & $0 \%$ & $3 \%$ & $36 \%$ & $48 \%$ & $13 \%$ \\
\hline 6 & $2 \%$ & $17 \%$ & $46 \%$ & $29 \%$ & $6 \%$ \\
\hline 7 & $0 \%$ & $4 \%$ & $18 \%$ & $48 \%$ & $30 \%$ \\
\hline 8 & $0 \%$ & $16 \%$ & $41 \%$ & $37 \%$ & $6 \%$ \\
\hline 9 & $1 \%$ & $6 \%$ & $44 \%$ & $45 \%$ & $4 \%$ \\
\hline 10 & $2 \%$ & $43 \%$ & $27 \%$ & $11 \%$ & $17 \%$ \\
\hline 11 & $1 \%$ & $50 \%$ & $29 \%$ & $14 \%$ & $6 \%$ \\
\hline 12 & $6 \%$ & $1 \%$ & $14 \%$ & $39 \%$ & $40 \%$ \\
\hline 13 & $9 \%$ & $13 \%$ & $17 \%$ & $51 \%$ & $10 \%$ \\
\hline 14 & $15 \%$ & $8 \%$ & $21 \%$ & $49 \%$ & $7 \%$ \\
\hline 15 & $8 \%$ & $9 \%$ & $15 \%$ & $29 \%$ & $39 \%$ \\
\hline 16 & $5 \%$ & $35 \%$ & $17 \%$ & $34 \%$ & $9 \%$ \\
\hline 17 & $16 \%$ & $2 \%$ & $13 \%$ & $32 \%$ & $37 \%$ \\
\hline 18 & $14 \%$ & $3 \%$ & $24 \%$ & $45 \%$ & $14 \%$ \\
\hline 19 & $4 \%$ & $44 \%$ & $25 \%$ & $22 \%$ & $5 \%$ \\
\hline 20 & $13 \%$ & $39 \%$ & $35 \%$ & $11 \%$ & $2 \%$ \\
\hline
\end{tabular}

The lowest awareness level was recorded regarding Islamic taxation. Only 5\% of respondents believed they were aware of the subject. At the same time all of them were wrong that such taxes were not levied in Russia. Thus, subjective assessment of awareness can be questioned for a good reason.

Hypotheses on tolerance towards socially oriented taxation exemplified by a mock tax with zakat attributes were checked through the ordered logit approach.

Statement 6 ('a special tax should be introduced in order to provide support for the socially disadvantaged') was chosen to study factors influencing commitment to paying taxes, the relation towards which was rendered with an ordered variable (Y). According to the survey conditions, the variable could become one of the four values where the lowest one was 'strongly disagree' with introducing the tax and the highest one - 'strongly agree' (observations that did not receive clear comments were excluded from the final model; thus, the model included 122 observations out of 127).

The initial set of factors proposed to define an opinion on socially oriented taxes included the following:

- $\quad$ nine ordered discreet variables taking the following values: ' 1 ' strongly disagree, ' 2 ' disagree, ' 3 ' agree, ' 4 ' strongly agree: relation to statements $1-5$ and 7-10 of the first block of the questionnaire focused on the perception of social equality; 

females);

a dummy variable correlating with respondent's gender (' 1 ' for males and ' 0 ' for - $\quad$ two dummy variables correlating with a respondent's year of study (' 1 ' for the 3 rd year students, ' 0 ' for others; ' 1 ' for the 2 nd year students; ' 0 ' for others).

Significant factors were selected based on the t-criterion at the $5 \%$ level of significance (the findings were tested by the authors at the conference 'The 27th IBIMA conference: Innovation management and education excellence vision 2020: from regional development sustainability to global economic growth': Lvova et al., 2016).

The generated model is following:

$$
Y=-0,58 * X_{1}+0,50 * X_{2}+1,00 * X_{3}+0,46 * X_{4}+1,31 * X_{5}
$$

Where $\mathrm{Y}$ is the relation to the introduction of a special socially oriented tax implying one of the four options:

If $\mathrm{Y} \leq \mathrm{Y}_{0}$ then 'strongly disagree';

$\mathrm{Y}_{0}<\mathrm{Y} \leq \mathrm{Y}_{1}$ then 'disagree';

$\mathrm{Y}_{1}<\mathrm{Y} \leq \mathrm{Y}_{2}$ then 'agree';

$\mathrm{Y}_{2}<\mathrm{Y}$ then 'strongly agree';

$\mathrm{X}_{1}$ - agreement with the statement that financial support of socially disadvantaged groups of people is a mandatory component for businesses in terms of social responsibility (statement 4);

$\mathrm{X}_{2}$ - agreement with the statement that non-government funds with freely available and transparent accounting statements should collect and distribute money for the support of the disadvantaged (statement 7);

$\mathrm{X}_{3}$ - personal readiness of a respondent to refuse from a part of income in order to support the disadvantaged (statement 8);

$\mathrm{X}_{4}$ - opinion that expenditures for the support of the disadvantaged should be take into account when levying taxes on private persons (statement 10);

$\mathrm{X}_{5}-2$ nd year students.

The detailed characteristics of the model are presented in Table. 4.

Table 4. Model of tolerance to socially oriented taxation (Ordered logistic regression)

\begin{tabular}{|c|c|c|c|c|}
\hline Variable & Coef. & Std. Err. & z-statistic & Probability \\
\hline $\mathrm{X}_{1}$ & -.579599 & .2680124 & -2.16 & 0.031 \\
\hline $\mathrm{X}_{2}$ & .502654 & .2363988 & 2.13 & 0.033 \\
\hline $\mathrm{X}_{3}$ & 1.001874 & .2457274 & 4.08 & 0.000 \\
\hline $\mathrm{X}_{4}$ & .459762 & .1670974 & 2.75 & 0.006 \\
\hline $\mathrm{X}_{5}$ & 1.315009 & .4765873 & 2.76 & 0.006 \\
\hline Cuts & & & & \\
\hline $\mathrm{Y}_{0}$ & 1.595964 & 1.064465 & & \\
\hline $\mathrm{Y}_{1}$ & 4.453875 & 1.12938 & & \\
\hline $\mathrm{Y}_{2}$ & 7.111679 & 1.259993 & & \\
\hline \multirow{3}{*}{ Log likelihood } & \multirow{3}{*}{-121.01352} & \multirow{3}{*}{\multicolumn{2}{|c|}{$\begin{array}{l}\text { Pseudo }-\mathrm{R}^{2} \\
\text { LR chi2(5) } \\
\text { Prob > chi2 }\end{array}$}} & 0.162 \\
\hline & & & & 47.02 \\
\hline & & & & 0.0000 \\
\hline
\end{tabular}

Commitment to the mock tax featuring zakat attributes is positively related to the agreements with statements $7,8,10$ and negatively related to the agreement with statement 4 . In other words, tolerance level in this case is defined by the readiness to refuse form a part of income in order to support the disadvantaged and the level of confidence in specialized nongovernment organizations. The chances of agreement with the introduction of a socially 
oriented tax are higher among 2nd year students compared to the 3rd and 4th year students. In our opinion, the reason for this is that junior students associate themselves less with tax payers.

The research has revealed that respondents' agreement with some of the statements is statistically insignificant including the agreement with the mandatory compliance of financial relations with strict ethical principles; the agreement with the goal to benefit socially fair distribution of profit in a society; the agreement that financial support of the disadvantaged should be provided by the government; the agreement that society as a whole is responsible for the financial support of the disadvantaged; with the agreement to make donations to support the disadvantaged at certain time and of certain size. It was interesting to find out that gender difference did not affect tolerance towards socially oriented taxation. It should be noted that most of the respondents shared the opinion that financial relations should benefit fair distribution of profit in a society.

A significant part of the respondents were ready to regularly make donations in order to support the disadvantaged. Nevertheless, not all of them agreed with the introduction of a special socially oriented tax. In our opinion, this allows us to conclude that the determining feature of any tax is its compulsory nature.

\section{Conclusion}

The research confirmed there is statistically significant relation between the perception of social responsibility (including mechanisms of its practical implementation) and the level of tolerance towards socially oriented taxation. Even though commercial education rapidly developed in the twentieth century (Karelskaya and Zuga, 2014), the awareness of tax mechanisms and their modifications remains quite low. According to the survey results, the would be economists did not know any specific examples of implementing unconventional tax mechanisms and at the same time were quite ready to assume additional social obligations.

The commitment to introduce a mock socially oriented tax with the zakat features is positively related to the following factors: readiness to refuse from a part of personal income in order to support socially disadvantaged groups, positive opinion on non-state management of socially oriented taxes, expecting corresponding tax reliefs for private persons.

Developing further the traditional perception of tax mechanisms within religious and socially oriented taxation, the survey results not only have scholarly importance, but also are of practical value. We believe that religious taxation can be successfully introduced in tax management in secular multicultural states including the Russian Federation. It is noteworthy that rather being oriented on compulsion, Islamic tax mechanisms are based on efficient motivation and implemented on innovative instruments. Thus, a tax payer who is surrounded with maximum comfort becomes involved and interested, what, in our opinion, creates important preconditions for a break-through in economic inequality within a society.

Making similar surveys among would-be economists in different parts of the Russian Federation seems to be a promising direction for further studies in this field as well as inviting representatives of academic and professional communities to take part in the discussion of unconventional tax mechanisms.

\section{Literature}

Abdullah, N., Derus, A., Al-Malkawi, H. (2015). The Effectiveness of Zakat in Alleviating Poverty and Inequalities: a Measurement Using a Newly Developed Technique. Humanomics, vol. 31, no. 3, pp. 314-329. 
Al-Qardawi, Yu. (2000). Fiqh al Zakah: A Comparative Study of Zakah, Regulations and Philosophy in the Light of Quran and Sunnah, vol. 1. Jeddah: Scientific Publishing Centre, King Abdulaziz University.

Awad, M. (2000) Adjusting Tax Structure to Accommodate of Zakah / Management of Zakah in Modern Muslim Society, Imtiazi, I. (ed). Jeddah: Islamic Development Bank, pp. 77-100.

Bekkin, R. I. (2007). Islamic Taxes in Tax Systems of Muslim Countries. Tax Policy and Practice, vol. 6, no. 54, pp. 42-47.

Gordeeva, O. E., Lvova, N. A. (2009). Islamic financial system. Vestnik SanktPeterburgskogo universiteta. Seriya 5: Ekonomika, no. 3, pp. 124-133. (in Russian)

Islamic Finance (2013). The UK Islamic Finance Secretariat (UKIFS) Report.

Available on-line at www.thecityuk.com/assets/Uploads/Islamic-finance-2013-F.pdf (accessed 10 September 2016).

Islamic Financial Services Industry Stability Report (2015).

Available on-line at /www.ifsb.org/docs/2015-0520_IFSB\%20Islamic\%20Financial\%20

Services\%20Industry\% 20Stability\%20Report\%202015_final.pdf (accessed 10 September 2016).

Kallimullina, M. E. (2010). Socio-cultural Factors in the National Model of the Russian Economics (Based on Sociological Research on Islamic Economics and Finance among Russian and Commonwealth of Independent States' Population). Economics. Business. Environment, vol. 2, no. 42, pp. 13-20.

Karelskaya, S., Zuga, E. (2014). First Institution of Higher Education in Russia. In: Proceedings of International Conference on Accounting, Auditing, and Taxation (ICAAT), pp. 269-276.

Lvova, N., Pokrovskaia, N. (2015). Special Features of Islamic Taxation in the Modern Financial System. Finance and credit, no. 8, pp. 31-40.

Lvova, N., Pokrovskaia, N., Ivanov, V. (2016). The Attitude to Islamic Taxation in Russia: Does Financial Ethics Matter? Innovation management and education excellence vision 2020: from regional development sustainability to global economic growth. The 27th IBIMA conference proceedings, pp. 294-304.

Masvood, Y., Lokeswara Choudary, Y. (2015). Islamic Banking - a Cross Cultural Patronage Study among the Students in Chennai. Asian Social Science, vol. 11, no. 4, pp. 310-318.

Mohd Ali, A., Rashid, Z., Johari, F., Aziz M. (2015). The Effectiveness of Zakat in Reducing Poverty Incident: An Analysis in Kelantan, Malaysia. Asian Social Science, vol. 11, no. 21, pp. 355-367.

Mohdali, R., Pope, J. (2014). The Influence of Religiosity on Taxpayers' Compliance Attitudes: Empirical Evidence from a Mixed-Methods Study in Malaysia. Accounting Research Journal, vol. 27, no. 1, pp. 71-91.

Powell, R. (2009). Zakat: Drawing Insights for Legal Theory and Economic Policy from Islamic Jurisprudence. University of Pittsburgh Tax Review, vol. 7, no. 43, pp. 43-101.

Religious Diversity Index Scores by Country (2014).

Available on-line at www.pewforum.org/2014/04/04/religious-diversity-index-scores-bycountry/ (accessed 10 September 2016).

Saleem, Sh. (1992). Islamic Concept of Taxation. Renaissance, no. 2 (10). 
Available on-line at www.monthly-renaissance.com/issue/content.aspx $? \mathrm{id}=1127$ (accessed 10 September 2016).

Shaikh S. (2009). An Alternate Approach to Theory of Taxation and Sources of Public Finance in an Interest Free Economy. MRPA Paper.

Yusuf M. \& Derus A. (2013). Measurement Model of Corporate Zakat Collection in Malaysia: A Test of Diffusion of Innovation Theory. Humanomics, vol. 29, no. 1, pp. 61-74. 